\title{
MODEL OF AN ARTIFICIAL REEF FOR INCREASING THE BIOPRODUCTIVITY OF DONUZLAV LAKE
}

\author{
T. P. Khairullina (a)*, T. L. Kalita (b)*, N. M. Naumov (c), A. Vaganova (d) \\ *Corresponding author
}

(a) K.G. Razumovsky Moscow State University of Technologies and Management (the First Cossack University) 73, Zemlyanoy Val str., Moscow, Russia, t.khayrulina@mgutm.ru

(b) K.G. Razumovsky Moscow State University of Technologies and Management (the First Cossack University) 73, Zemlyanoy Val str., Moscow, Russia, t.kalita@mgutm.ru

(c) K.G. Razumovsky Moscow State University of Technologies and Management (the First Cossack University) 73, Zemlyanoy Val str., Moscow, Russia

(d) Moscow State University of Civil Engineering, Moscow, Russia

\begin{abstract}
The development and installation of artificial reefs involves solving several practical problems at once: increasing biological productivity, accelerating the processes of natural water purification from nutrients, increasing the recreational potential of the water area, improving the efficiency of fishing, and they should also serve as breakwaters, protect the coastline from erosion and prevent bottom trawling. Currently, new environmentally friendly technologies for creating artificial reefs have been developed. These technologies include: Biorock technology (due to electro-mineral accretion) and ReefBall. The paper proposes a model of an artificial reef based on the combination of these two technologies. The scheme of the 3D model of the reef, made in the AutoCad environment, is proposed. The model was developed for Lake Donuzlav and it was supposed to be placed along the coast of the Tarkhankutsky Natural Park (Crimea Peninsula). Donuzlav, is the need to protect aquatic organisms-filter feeders from mollusks-predators Rapana venosa. Therefore, it is necessary to provide for the need to place the main part of the reef in the water column, and not at the bottom. For this purpose, the most optimal solution is to attach the bearing part of the reef to the buoy. However, the rigidity of the structure will lead to its instability due to currents and eddy currents, therefore, to smooth them out, it is proposed to attach the reef to the bottom using chains that create a crinoline around the buoy cable.
\end{abstract}

2672-8575 (C) 2022 Published by European Publisher.

Keywords: Artificial reef, BIOROCK® technology, biofilter, increased productivity, ReefBall 


\section{Introduction}

The construction of artificial reefs has been known to mankind since the time of Ancient Persia. At that time, reefs were used as strategic structures that prevented the penetration of enemies into the internal waters of the country. Artificial reefs were used exclusively for military purposes until the 17th century.

Around the 17th century, Japan began to make reefs from rubble and stone, which were used for growing algae and fishing. Massive reef construction to improve fishing productivity began in the United States of America in the 1830s. These structures were built of intertwined logs and were used exclusively for economic purposes. Projects for the construction of reefs from ships, subway cars, battle tanks, drilling rigs, etc. were officially approved, which contributed to the appearance of various toxicants in the water around the reefs (Aleksandrov, 2018).

Currently, new developments have appeared to minimize the negative impact of the implemented facilities on the environment. One of these technologies is based on the process of electro-mineral accretion (EMA): an electrically conductive frame is placed at the bottom of the water area, to which a low voltage current is applied, as a result of which bubbles of oxygen and chlorine are formed at the anode, which are released into the atmosphere, and at the cathode - gaseous hydrogen and limestone deposits. As a result, crystals of calcium carbonate and magnesium hydroxide appear on the structure, on which the larvae of aquatic organisms easily settle. The voltage required for the installation is so low that it can be generated by wave power plants or solar panels. In this way, reefs were formed off the coast of the city of Pemuteran, Bali (Goreau, 2013).

Another effective technology for creating artificial reefs has been developed by the Reef ball Foundation called Reefball. According to the technology, reefs are made of microsilica concrete, which does not allow the admixture of plastic, metal, rubber, nylon (Reef ball Foundation, n.d.). The production of reefballs in the Russian Federation is closely monitored by the non-profit charitable foundation for the development of underwater environmental programs "Artificial Reefs", accredited by the owner of the technology due to strict requirements for the composition of concrete. The developers of these reefs guarantee a service life of at least 500 years, which is an order of magnitude longer than the service life of conventional concrete reefs (50-70 years). These facilities are economical and environmentally friendly, and they also have a flexible lineup (Artificial reefs Reef Ball, n.d.). An equally important factor is the ability to install reefballs in various ways: with the help of divers, a crane attached to a barge or boat, air bags. Reef ball can be used as anchors for oyster farms, obstacles for bottom trawling.

It should be noted that any type of artificial reef increases the productivity of the reservoir. It was shown that productivity increases from 1.6 to 1.8 times in terms of the number of individuals and from 1.5 to 2.3 times in mass during the year from the moment the object was created. Many authors (Kuznetsov et al., 2015; Lokesha \& Sannasiraj, 2013; Markevich, 2005; Popova, 2004; Yavnov \& Gladkikh, 2001) note that artificial reefs not only increase biological productivity, but also accelerate the processes of natural water purification from nutrients, improve opportunities for diving, industrial and recreational fishing, serve as breakwaters, protect the coastline from erosion, and also prevent bottom trawling, a fishing method prohibited in the territory of the Russian Federation. 
The installation of artificial reefs in the water area of deep-water fresh water bodies (lakes, reservoirs) is usually associated with the need to concentrate hydrobionts in fishing zones (Hammond et al., 1977: Hubbs, 1930; Kuznetsov et al., 2015; Prince, 1976). The second, no less important task is the creation and use of artificial reefs as biofilters to improve the water quality of fresh water bodies. The latter problem is solved by installing reefs in the form of brushes made from freshly cut branches of oak, conifers (Prince et al., 1977) or plastic (Prazukin et al., 2016), sometimes clay pipes or concrete blocks are added to them (Prince et al., 1977).

Well-designed artificial reefs usually solve another problem - using them as an effective recreational resource for diving. In 2006, the first Moilinere Bay Underwater Sculpture Park was built by the sculptor deCaires Taylor (Figure 1; Kirkbride-Smith, 2014; Taylor, n.d.). Underwater parks and museums are now located in many places of the World Ocean, but their creation in fresh water bodies has not yet been fully thought out.

\section{Purpose of the Study}

Therefore, the goal of this work was to develop artificial reefs for deep-water fresh and brackish water bodies (lakes, reservoirs, estuaries) based on new production technologies.

\section{Research Methods}

Lake Donuzlav of variable salinity (from sea in the mouth on the border with the Black Sea to fresh in the upper reaches) was chosen as a deep-water fresh water body (Figure 2). The lake is located 30 $\mathrm{km}$ from Evpatoria (Crimea Peninsula, the Black Sea) and is separated from the sea by a sand spit $12 \mathrm{~km}$ long and $0.3-1 \mathrm{~km}$ wide. At the moment, the lake is experiencing significant anthropogenic pressure (intake of nutrients and pesticides from agricultural land, domestic wastewater in residential areas, destruction of the banks by sand mining enterprises) (Ivanyutin, 2019). In the northwestern part of the lake is the Tarkhankutsky Natural Park (founded in 2009), created to preserve the unique wetland flora and fauna. It is planned to place reefs along the coast of the park at a depth of $10 \mathrm{~m}$ and a salinity of about $15 \%$ to improve water quality and increase the recreational potential of the water area.

AutoCad software was used to create a 3D model of the reef.

\section{Findings}

The fundamental factor determining the design of the artificial reef for the lake. Donuzlav, is the need to protect aquatic organisms-filter feeders from mollusks-predators Rapana venosa. Therefore, it is necessary to provide for the need to place the main part of the reef in the water column, and not at the bottom. For this purpose, the most optimal solution is to attach the bearing part of the reef to the buoy. However, the rigidity of the structure will lead to its instability due to currents and eddy currents, therefore, to smooth them out, it is proposed to attach the reef to the bottom using chains that create a crinoline around the buoy cable. 
The supporting part of the reef must be grown using the Biorock technology (electro-mineral accretion), as a source of electricity, it is possible to use solar panels or wind turbines installed at the top of the reef.

It is advisable to use the anchor as another useful part of the reef, therefore, it is possible to use the Reefball technology here, which guarantees the durability and environmentally friendly superplasticizers and concrete additives.

Based on the calculated mass of aquatic organisms, a buoy with a diameter of 2.4 meters and a buoyancy of $850 \mathrm{~kg}$ was chosen. To anchor such a buoy with all its components, you need an anchor weighing $1003 \mathrm{~kg}$ (GOST 26645-85) with a chain diameter of $22 \mathrm{~mm}$. The length of the chain from the buoy to the ReefBoll is 13 meters.

A functional 3D model of the reef and its visualization in compliance with the necessary parameters and criteria is shown in Figure 3 with the provisional name "Revivalis".

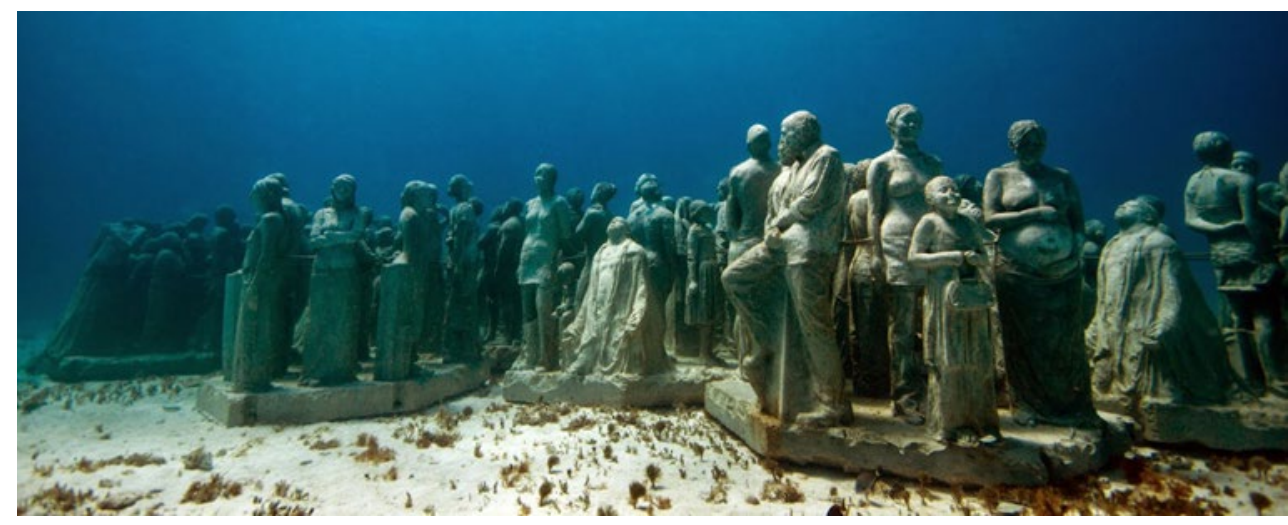

Figure 1. «Silent Evolution» by Jason de Caires. Underwater Sculpture Park in Cancun, Mexico (Taylor, n.d.)

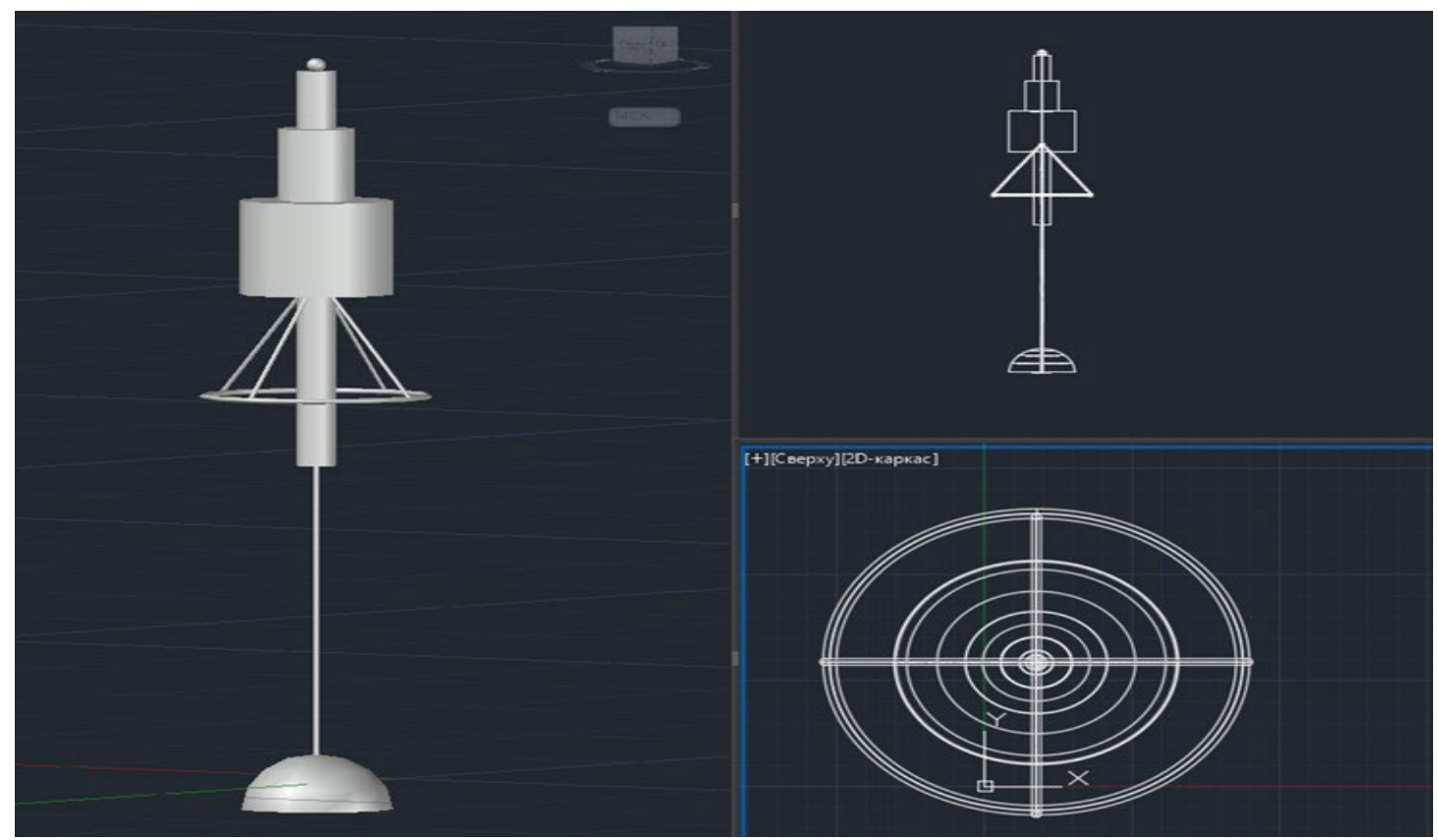

Figure 2. 3D model of an artificial reef «Revivalis» in the program AutoCad (facade and plan) 


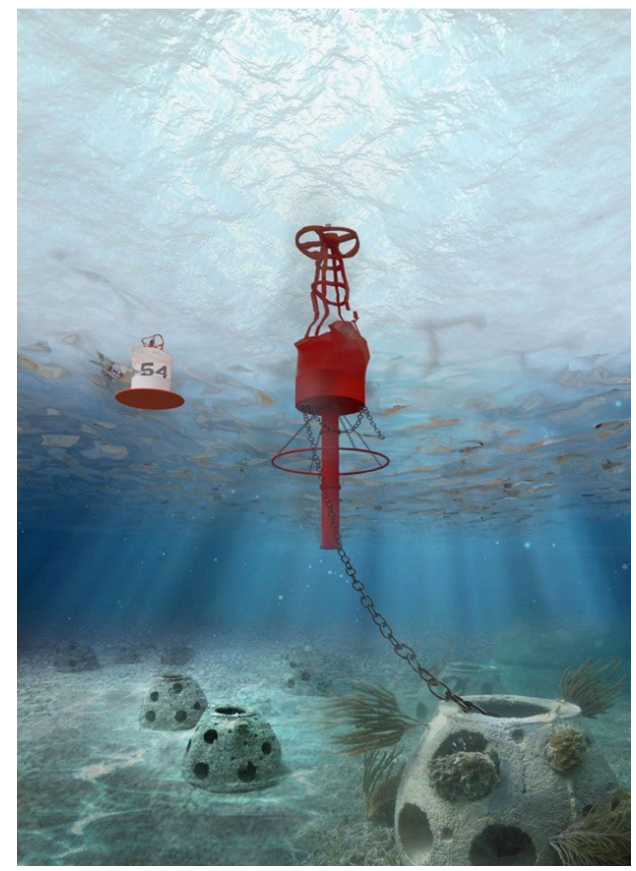

Figure 3. Scheme - visualization of a model of the "Revivalis" artificial reef in Donuzlav lake

\section{Conclusion}

Thus, the developed model of an artificial reef allows solving several practical problems: increasing biological productivity, accelerating the processes of natural water purification, increasing the recreational potential of the water area and the efficiency of fishing, as well as preventing bottom trawling. To create a reef, it is proposed to use new environmentally friendly technologies: Biorock technology (due to electro-mineral accretion) and ReefBal.

\section{References}

Aleksandrov, B. G. (2018). Artificial reefs as a means of rehabilitation of aquatic ecosystems. Experience of the Black Sea countries. https://infourok.ru/iskusstvennye-rify-kak-sredstvo-reabilitacii-vodnyhekosistem-opyt-chernomorskih-stran-4845847.html

Artificial reefs Reef Ball. (n.d.). Retrieved on 22 May, 2021, from http://artificialreefs.ru/

Goreau, T. J. (2013). BIOROCK ${ }^{\circledR}$ technology: The most cost-effective method for solving major marine resource management problems including construction and repair, shore protection, ecological restoration, sustainable aquaculture, and climate change adaptation. Biorock Technology Inc., 19.

Hammond, D. L., Myatt, D. O., \& Cupka, D. M. (1977). Evaluation of midwater structures as a potential tool in the management of the fisheries resources of South Carolina's artificial fishing reefs. South Carolina Marine Resources Center, Technical Report Series, 15, 19.

Hubbs, C. L. (1930). Fishery research in Michigan. Transactions of the American Fisheries Society 30, 182-185. https://doi.org/10.1577/1548-8659(1930)60[182:FRIM]2.0.CO;2

Ivanyutin, N. M. (2019). Modern ecological state of Donuzlav lake. Water and ecology: problems and solutions, 3(79), 47-58. https://doi.org/10.23968/2305-3488.2019.24.3.47-58

Kirkbride-Smith, A. E. (2014). The Economic, Social and Conservation Benefits of Recreation-orientated Artificial Reefs [Doctoral dissertation]. School of Biological Sciences in the University of Hull. Digital Repository. https://hydra.hull.ac.uk/assets/hull:11669a/content 
Kuznetsov, V. V., Kuznetsova, E. N., Goncharov, S. M., Popov, S. B., Belorustseva, S. A., \& Mititello, A. V. (2015). Assessing the impact of artificial reefs on freshwater aquatic community. Aquatic biological resources, $155,69-78$.

Lokesha, S. V., \& Sannasiraj, S. A. (2013). Artificial Reefs: A Review. International Journal of Ocean and Climate Systems, 4(2), 117-124. https://doi.org/10.1260/1759-3131.4.2.117

Markevich, A. I. (2005). The dynamics of fish population in the experimental artificial reef in the Peter the Great Bay. Russian Journal of Marine Biology, 31(4), 262-266. https://doi.org/10.1007/s11179-005-0076-8

Popova, N. V. (2004). Bioecological foundations and practical results of the development of a system for protecting the biological diversity of the Caspian Sea from oil pollution. Doctoral dissertation, Astrakhan State Technical University. Russian State Library. https://www.google.ru/url?sa=t\&rct=j\&q=\&esrc=s\&source=web\&cd=\&ved=2ahUKEwif9JHe1L3 xAhVhw4sKHdhZCqE4ChAWMAJ6BAgEEAM\&url=http\%3A\%2F\%2Fdl1.lib.uaru.net\%2Ffiles\%2Fdfd\%2F308\%2F050260034.doc\&usg=AOvVaw0hvwN8AR2pKHdkgQbpWhX

Prazukin, A. V., Firsov, Y. K., Kholodov, V. V., \& Lee, R. I. (2016). Seasonal dynamics of biofouling of artificial reef structures in the eutrophied sea area. Marine biological research: achievements and prospects: in 3 volumes: collection of articles. materials Vseros. scientific-practical conf. with int. participation, timed. to the 145th anniversary of the Sevastopol Biological Station, 3, 432-435.

Prince, E. D. (1976). Biological effects of artificial tire reefs in Smith Mountain Lake, VA. Blacksburg.

Prince, E. D., Maughan, O. E., \& Brouha, P. (1977). How to build a freshwater artificial reef. Virginia Polytechnic Institute and State University.

Reef Ball Foundation. (n.d.). Retrieved on 3 May, 2021, from www.reefball.com

Taylor, J. de C. (n.d.). Overview. Retrieved May 22, 2021, https://www.underwatersculpture.com/about/overview/?doing_wp_cron=1624805045.1745779514 312744140625

Yavnov, S. V., \& Gladkikh, G. N. (2001). Changing the phytoplankton community in the areas of productions of artificial reefs in coastal waters of Primorye. Izvestiya TINRO, 12, 902-906. 